đột biến exon 19, toàn trạng tốt, có đáp ứng tại thời điểm 3 tháng và không hoặc di căn 1 cơ quanngoài não.

- Trung vị PFS tại não đạt 11 tháng.

- Cần thêm thời gian theo dõi để đưa ra kết quả cuối cùng của nhóm điều trị kết hợp với gamma knife.

\section{TÀI LIÊU THAM KHẢO}

1. Sung, H. et al. Global Cancer Statistics 2020: GLOBOCAN Estimates of Incidence and Mortality Worldwide for 36 Cancers in 185 Countries. CA: A Cancer Journal for Clinicians71, 209-249 (2021).

2. Tamura, T. et al. Specific organ metastases and survival in metastatic non-small-cell lung cancer. Molecular and Clinical Oncology3, 217-221 (2015).

3. Dang, A.-T. H. et al. Actionable Mutation Profiles of Non-Small Cell Lung Cancer patients from Vietnamese population. Sci Rep10, 2707 (2020).

4. Moumtzi, D. et al. Prognostic factors for long term survival in patients with advanced non-small cell lung cancer. Ann Transl Med4, 161 (2016).

5. Yang, W.-C. et al. Epidermal growth factor receptor mutation predicts favorable outcomes in non-small cell lung cancer patients with brain metastases treated with stereotactic radiosurgery. Radiotherapy and Oncology126, 368-374 (2018).

6. Nguyê̂n Thị Thanh Huyền, Lê Văn Quảng Nguyển Thị Thái Hòa. Đánh giá kết quả điêu trị ung thư phổi không tế bào nhỏ di căn não đột biến EGFR bằng Erlotinib có hoặc không kết hợp với xạ tri tai não, (2018).

7. Magnuson, $\mathbf{W}$. J. et al. Management of Brain Metastases in Tyrosine Kinase Inhibitor-Naïve Epidermal Growth Factor Receptor-Mutant Non-SmallCell Lung Cancer: A Retrospective Multi-Institutional Analysis. J Clin Oncol35, 1070-1077 (2017).

8. Gerdan, L. et al. Brain metastasis from non-small cell lung cancer (NSCLC): prognostic importance of the number of involved extracranial organs. Strahlenther Onkol190, 64-67 (2014).

\title{
PHÂN TÍCH CHI PHÍ TRỰC TIẾP CHO Y TẾ VÀ CÁC YẾU TỐ LIÊN QUAN Ở BỆNH NHÂN ĐÁI THÁO ĐƯỜNG TYPE 2 ĐIỀU TRI NGOẠI TRÚ BỆNH TẠI BỆNH VIÊ̂N ĐA KHOA KHU VỰC LONG KHÁNH
}

\section{Nguyễn Thanh Hùng ${ }^{1}$, Nguyễn Thị Quỳnh $\mathrm{Nga}^{2}$, Lê Đăng Tú Nguyên ${ }^{2}$ Trương Văn Đạt ${ }^{2}$, Trần Đình Trung ${ }^{3}$, Nguyễn Thị Hải Yến ${ }^{2 *}$ \\ SUMMARY \\ ANALYSIS OF DIRECT MEDICAL COSTS AND RELATED FACTORS IN TYPE 2 DIABETES \\ PATIENTS IN OUTCOME TREATMENT AT LONG KHANH REGIONAL HOSPITAL}

\section{TÓM TẮT}

Mục tiêu: Phân tích chi phí trực tiếp cho y tế và các yểu tố liên quan ở bênh nhân điêu trị ngoai trú bệnh đái tháo đường (ĐTĐ) type 2 tại Bệnh viện Đa khoa khu vức Long Khánh giai đoan 2016-2020. Phương pháp: Nghiên cứu mô tả cắt ngang, hồi cứu toàn bộ bệnh án của 3.452 người bệnh ĐTĐ type 2 giai đoạn 2016-2020 theo quan điểm của người bênh và bảo hiểm y tế. Kết quả: Tổng chi phí điều trị là 31.581.327.511 VND, trong đó BHYT chi trả $64,6 \%$ và người bệnh cùng chi trả 35,4\%. Chi phí trung bình cho điêu trị môt ca giảm dần theo thời gian. Các yếu tố liên quan đến chi phí điều trị bao gồm giới tính, nơi cư trú, bệnh kèm, mức bảo hiểm y tế, sử dung các dịch vụ y tế. Kết luận: Kết quả nghiên cứu cung cấp thông tin khách quan về cấu phẩn chi phí cũng như các yếu tố liên quan đến chi phí điều trị bệnh ĐTĐ type 2 tại bệnh viện, từ đó hố trợ điêu chỉnh chính sách phù hợp với chi phí từ quỹ BHYT chi trả cho người bệnh tham gia BHYT theo đúng pháp luật.

Tư khóa: Chi phí trực tiếp cho y tế, Đaái tháo đường type 2, Điều trị ngoại trú.

\footnotetext{
${ }^{1}$ Bênh viện Đa khoa Khu vức Long Khánh

2Đại học Y Dược Thành phố Hồ Chí Minh

${ }^{3}$ Trường Đại hoc Kỹ thuât Y - Dược Đà Nẵng.

Chịu trách nhiểm chính: Nguyễn Thị Hải Yến

Email: haiyen@ump.edu.vn

Ngày nhận bài: 23.8.2021

Ngày phản biên khoa hoc: 18.10.2021
}

Ngày duyệt bài: 26.10.2021
Objective: Analyze direct medical costs and related factors in outpatients with type 2 diabetes mellitus (DM) at Long Khanh Regional General Hospital in the period 2016-2020. Methods: A crosssectional, retrospective descriptive study of all 3,452 patients with type 2 diabetes in the period 2016-2020 from the patient's point of view and health insurance. Results: The total cost of treatment is $31,581,327,511$ VND, of which health insurance covers $64.6 \%$ and the patient jointly pays $35.4 \%$. The average cost of treating a case decreases over time. Factors related to the cost of treatment include gender, place of residence, comorbidities, health insurance level, use of medical services. Conclusion: The research results provide objective information about the cost components as well as the factors related to the cost of treating type 2 diabetes at the hospital, thereby supporting policy adjustment in line with the cost. Fees from the health insurance fund shall be paid to patients participating in health insurance in accordance with the law.

Keywords: Direct medical expenses, Type 2 diabetes, Outpatient treatment.

I. ĐĂTT VẤN ĐỀ

Đái tháo đường (ĐTĐ) type 2 là một trong 
những bệnh không lây nhiễm phổ biến trên toàn câuu. Năm 2019, trên toàn thế giới có 463 triệu người lớn có độ tuổi 20-79. Dự đoán vào năm 2045, sẽ tăng tới khoảng 700 triêu người. Theo Tổ chức Y tế Thế giới (WHO) dự đoán đến năm 2040 số người bị ĐTĐ sẽ là 642 triệu người, Theo thống kê Liên đoàn Đái tháo đường Quốc tế (IDF), năm 2019 toàn thế giới có 463 triệu người trong độ tuổi 20-79 bị bệnh ĐTÐ, dự kiến sẽ có 578 triệu người vào năm 2030 và tiểp tục sẽ tăng đến 700 triệu người vào năm 2045 [1, 2].

ở Việt Nam, Theo kết quả điều tra do Bộ Y tế thực hiện năm 2015 ở nhóm tuổi từ 18-69, cho thấy tỷ lệ ĐTĐ toàn quốc là $4,1 \%$, tiền ĐTĐ là $3,6 \%$, trong đó tỷ lệ ĐTĐ được chẩn đoán là $31,1 \%$, tỷ lệ ĐTĐ chưa được chẩn đoán là 69,9\% [3]. Trong số những người bệnh được chẩn đoán, tỷ lệ ĐTĐ được quản lý tại cơ sở y tế $28,9 \%$, tỳ lệ ĐTंĐ chưa được quản lý $71,1 \%$. Dữ liệu cập nhật của IDF cho thấy năm 2019 Việt Nam có tỷ lệ $6 \%$ người trưởng thành mắc bệnh ĐTÐ type 2, chi phí trung bình cho điều trị của mỗi người bệnh là 162,7 USD/năm $[2,4]$. Tỷ lệ mắc ĐTÐ ngày càng tăng không chỉ ở khu vực thành phố mà còn phát triển nhanh ở khu vực nông thôn. Người mắc bệnh ĐTÐ type 2 được phát hiện muộn sẽ kèm theo các biến chứng nặng nề [5]. Chính vì vậy, nghiên cứu được thực hiện với các mục tiêu cụ thể (1) Phân tích chi phí trực tiếp y tế cho điều trị ngoại trú bệnh ĐTĐ type 2 tại Bệnh viện Đa khoa khu vực Long Khánh giai đoạn 2016-2020; (2) Phân tích các yếu tố liên qua cho điều trị ngoại trú bệnh đái tháo đường type 2 tại Bệnh viện Đa khoa khu vực Long Khánh.

\section{II. ĐỐI TƯợNG VÀ PHƯƠ'NG PHÁP NGHIÊN CỨU}

2.1. Đối tượng nghiên cứu. Hồ sơ bệnh án ngoại trú của người bệnh thỏa mãn các tiêu chí sau:

Tiêu chí đưa vào: Được chẩn đoán bệnh ĐTÐ type 2 (E11-ĐTÐ không phụ thuộc insulin). Người bệnh tuân thủ điều trị trong thời gian từ 01/01/2016 đến 31/12/2020.

Tiêu chí loại ra: Hồ sơ bệnh án không đủ thông tin nghiên cứu. Phụ nữ mang thai có ĐTÐ thai kỳ.

2.2. Thời gian và địa điểm nghiên cứu

Thời gian: 6 tháng (02/2021 - 07/2021)

Địa điểm: Bệnh viện Đa khoa khu vực Long Khánh.

\subsection{Phương pháp nghiên cứu}

2.3.1. Thiết kế nghiên cứu. Nghiên cứu mô tả cắt ngang, sử dụng phương pháp hồi cứu bệnh án ngoại trú trong giai đoạn 2016-2020.

2.3.2. Cớ mấu và phướng pháp chọn mẫu. Chọn mẫu toàn bộ, được 3.452 bệnh án ngoại trú ĐTÐ type 2 trong giai đoạn 2016-2020 theo sơ đồ lựa chọn (Hình 2.1).

\subsubsection{Nội dung nghiên cứu}

*Phân tích chi phí trực tiếp cho y tế: Xác định cơ cấu và tính toán chi phí trực tiếp y tế.

Phương pháp thống kê mô tả các đặc điểm của người bệnh, các dịch vụ y tế và chi phí trực tiếp y tế cho điều trị bệnh ĐTĐ type 2 .

Dữ liệu chi phí trực tiếp y tế được mô tả bằng giá trị trung bình và độ lệch chuẩn; khoảng tin cậy $95 \%$; trung vị và khoảng tứ phân vị.

Xác định thành phần chi phí: Chi phí điều trị theo quan điểm của người bệnh và BHYT là chi phí trực tiếp y tế, bao gồm các thành phần chi phí khám bệnh, thuốc, xét nghiệm, chẩn đoán hình ảnh và khác [7].

Tính toán chi phí điều trị: Chi phí trực tiếp y tễ $=$ Chi phí khám bệnh + Chi phí thuốc + Chi phí xét nghiệm + Chi phí chẩn đoán hình ảnh + Chi phí khác.

*Phân tích chi phí trung bình điêu trị ngoại trú: Tổng chi phí điều trị ĐTĐ type 2 được phân tích mô tả và so sánh giữa các nhóm dân số phân tầng theo các đặc điểm dân số xã hội, bệnh lý, tình trang BHYT và mức độ sử dụng dịch vụ y tế. Do đặc điểm của biến sổ tổng chi phí điểu trị, phép kiểm Kruskal-Wallis được sử dụng cho biến số phân nhóm có từ 3 nhóm trở lên (nhóm tuổi, nơi cư trú, tình trạng BHYT) và phép kiểm Mann-Whitney được sử dụng cho biến số phân nhóm có 2 nhóm (giới tính, có/không có chẩn đoán phụ, có/không có bệnh mắc kèm, có/không có các dịch vụ y tế).

*Phân tích các yểu tố liên quan đến chi phí trực tiếp cho y tế:

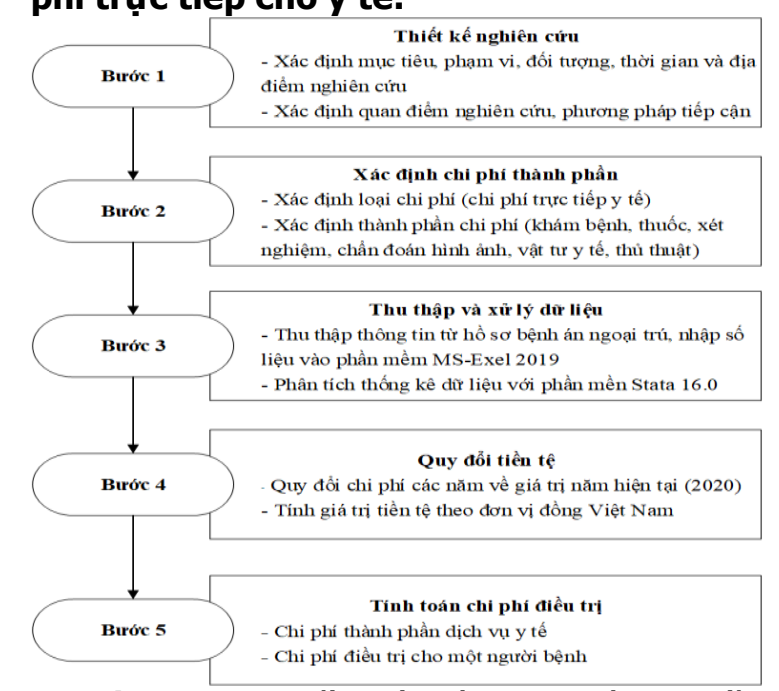

Hình 2.1. Sơ đồ phân tích chi phí trực tiếp y 
tế cho điều trị ngoại trú bệnh đái tháo đường type 2 tại Bệnh viện Đa khoa khu vực Long Khánh giai đoạn 2016-2020

Mô hình GLM đơn biến được thực hiện để phân tích mối liên hệ giữa từng biến số đặc điểm dân số xã hội, bệnh lý, mức độ sử dụng dịch vụ y tế với Tổng chi phí điều trị bệnh ĐTĐ type 2.

Đối với các biến số có mối liên hệ đạt mức ý nghĩa thống kê, mô hình GLM đa biến được thực hiện sau đó để phân tích mối liên hệ giữa các biến số đặc điểm dân số xã hội, bệnh lý và mức đô sử dung dịch vu y tế với Tổng chi phí điều tri ĐTÐ type 2, với sự điều chỉnh của các biến số còn lại. Kết quả mô hình được trình bày dưới dạng giá trị phân tích biên sau mô hình GLM.

2.3.4. Phương pháp thu thập thông tin

Trích xuất số liệu nghiên cứu từ nguồn dữ liêu điện tử của bệnh viện, tổng hợp, sàng lọc bằng phần mềm Excel 2019.

2.3.5. Xử lý và phân tích số liệu. Xử lý thống kê và phân tích dữ liệu bằng phần mềm Stata 16.0.

Thống kê mô tả: Tân số, tỷ lệ phần trăm, trung bình, độ lệch chuẩn, trung vị, khoảng tứ phân vị.

Phân tích thống kê: Kiểm định so sánh giữa các tỷ lệ bằng phép kiểm Chi bình phương $x^{2}$ hoặc Chính xác Fisher, sự khác biệt có ý nghĩa thống kê nếu $p<0,05$; Kiểm định so sánh giá trị trung bình, trung vị giữa các nhóm bằng phép kiểm t-test hoặc Mann-Whitney, ANOVA một chiêu hoặc Kruskal-Wallis, sự khác biệt có ý nghĩa thống kê nếu $p<0,05$ [6]. Áp dụng mô hình hồi quy tuyến tính tổng quát (GLM) để phân tích mối liên quan của các biến số đối với chi phí trực tiếp cho y tế.

\section{KẾT QUẢ NGHIÊN CỨU}

Trong giai đoạn 2016-2020, nghiên cứu ghi nhận có 3.452 người bệnh ngoại trú điều trị đái tháo đường type 2 tại bệnh viện ĐKKV Long Khánh, tương ứng với tổng số lượt điều trị là 48.470 (Hình 3.1).

Kết quả nghiên cứu trên toàn bộ các ca bệnh ngoại trú điều trị ĐTĐ type 2 giai đoạn 20162020 có tổng chi phí điều trị của tất cả các ca bệnh trong 05 năm là 31.581.327.511 VND, trong đó chi phí thuốc là 26.517.208.702 VND luôn là chi phí cao nhất trong các loại dịch vụ y tế.

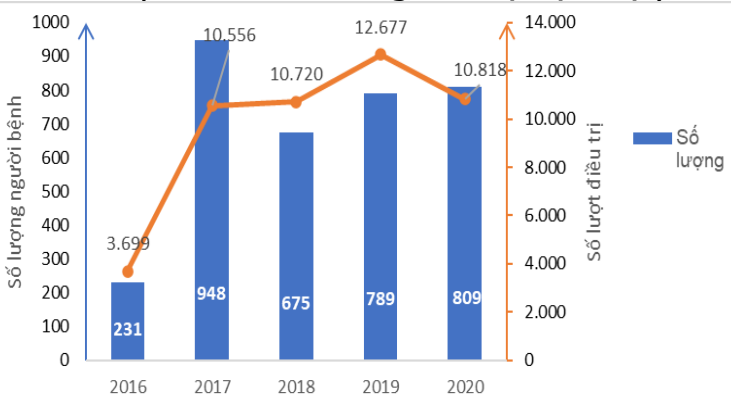

Hình 3.1. Số lượng và số lượt người bệnh ngoại trú điều trị đái tháo đường type 2 giai đoan 2016-2020

Bảng 3.1. Tổng chi phí dịch vụ y tế cho các ca bệnh ngoại trú điều trị đái tháo đường type 2 giai đoạn 2016-2020

\begin{tabular}{|c|c|c|c|}
\hline \multirow{2}{*}{ Dịch vụ y tế } & \multicolumn{2}{|c|}{ Nguû̀n thanh toán (VND) } & \multirow{2}{*}{ Tổng chi trả } \\
\cline { 2 - 3 } & Bảo hiếm y tế & Người bệnh & \\
\hline Khám bệnh & 950.691 .999 & 568.296 .826 & 1.518 .988 .825 \\
\hline Thuốc & 17.073 .792 .812 & 9.443 .415 .890 & 26.517 .208 .702 \\
\hline Xét nghiệm & 2.315 .504 .725 & 1.103 .582 .918 & 3.419 .087 .643 \\
\hline Chấn đoán hình ảnh & 60.753 .513 & 49.083 .644 & 109.837 .157 \\
\hline Khác & 9.827 .823 & 6.377 .361 & 16.205 .184 \\
\hline Tống cộng & $\mathbf{2 0 . 4 1 0 . 5 7 0 . 8 7 2}$ & $\mathbf{1 1 . 1 7 0 . 7 5 6 . 6 3 9}$ & $\mathbf{3 1 . 5 8 1 . 3 2 7 . 5 1 1}$ \\
\hline
\end{tabular}

So sánh chi phí trung bình điều trị cho 1 ca bệnh ĐTĐ type 2 điều trị tại bệnh viện trong giai đoạn 2016-2020, nhận thấy chi phí điều trị của năm 2016 là cao nhất 766.778 VND, chi phí thấp nhất ở năm 2020 là 562.960 VND. Có sự khác biệt có ý nghĩa thống kê đối với chi phí điều trị trung bình $(p<0,001)$.

Bảng 3.2. Chi phí trung bình cho điều trị đái tháo đường type 2 giai đoạn 2016-2020

\begin{tabular}{|c|c|c|c|c|}
\hline \multirow{2}{*}{ Năm } & \multicolumn{4}{|c|}{ Chi phí } \\
\hline & Trung bình (Độ lệch chuấn) & p-value* & Trung vị [Khoảng tứ phân vị] & p-value** \\
\hline 2016 & $766.778(391.333)$ & \multirow{5}{*}{$<0,001$} & $705.332[499.119 ; 971.851]$ & \multirow{5}{*}{$<0,001$} \\
\hline 2017 & $674.728(537.787)$ & & $633.069[200.104 ; 1.067 .935]$ & \\
\hline 2018 & $636.130(223.744)$ & & $599.549[446.052 ; 772.674]$ & \\
\hline 2019 & $590.078(203.780)$ & & $572.666[468.139 ; 706.698]$ & \\
\hline 2020 & $562.959(244.947)$ & & $529.567[421.370 ; 684.420]$ & \\
\hline
\end{tabular}

Ghi chú: *Kiểm định ANOVA một chiều, **Kiểm định Kruskal-Wallis. 
Kết quả phân tích hồi quy đơn biến các nhóm cho thấy giới tính nam có chi phí trung bình thấp hơn 22.541 VND so với nữ; Người bệnh ở khu vực huyện Xuân lộc có chi phí trung bình thấp hơn khu vực thành phố Long Khánh là 24.057 VND. Người bệnh có bệnh kèm có chi phí trung bình thấp hơn 128.870 VND so với không có bệnh kèm; Người bệnh tham gia dịch vụ y tế thì có sử dụng thuốc có chi phí trung bình cao hơn 610.204 VND so với không sử dụng thuốc, có xét nghiệm có chi phí trung bình cao hơn 152.963 VND so với nhóm không xét nghiệm, có chẩn đoán hình ảnh có chi phí trung bình cao hơn 209.870 VND so với không chẩn đoán hình ảnh và người bệnh tham gia dịch vụ khác có chi phí trung bình cao hơn 122.850 VND so với nhóm không tham gia có sự khác biệt có ý nghĩa thống kê $(p<0,001)$.

Kết quả phân tích hồi quy đa biến cho biết hệ số tác động của từng thông số và ảnh hưởng làm gia tăng chi phí của mỗi biến hồi quy so với đặc tính nền của phân tích. Từ kết quả phân tích, nghiên cứu đã ghi nhận được các biến ảnh hưởng có ý nghĩa thống kể đến chi phí điều trị ĐTÐ type 2 của người bệnh tại bệnh viện là nhóm tuổi từ 70-79 tuổi, nơi cư trú ở huyện Xuân Lộc, có mắc bệnh kèm và có tham gia các dịch vụ y tế $(p<0,001)$.

Bảng 3.3. Mô hình hồi quy phân tích các yêu tố liên quan đến chi phí điều trị bệnh đái tháo đường type 2

\begin{tabular}{|c|c|c|c|c|}
\hline \multirow[b]{2}{*}{ Biến số } & \multirow{2}{*}{\begin{tabular}{|c|} 
Mố hình đơn \\
biếna (VND)
\end{tabular}} & \multicolumn{3}{|c|}{ Tống chi trả } \\
\hline & & 95\% KTCc & $\begin{array}{l}\text { Mố hình đa } \\
\text { biếnb (VND) }\end{array}$ & 95\% KTCc \\
\hline \multicolumn{5}{|c|}{ Giới tính } \\
\hline Nam & $-22.541(p<0,001)$ & {$[-28.643 ; 16.440]$} & $-7.847(p=0,009)$ & {$[-13.740 ;-1.954]$} \\
\hline Nữ & - & - & - & - \\
\hline \multicolumn{5}{|c|}{ Nhóm tuối } \\
\hline$\leq 39$ & - & - & - & - \\
\hline $40-49$ & $-38.667(p=0,031)$ & {$[-73.876 ;-3.458]$} & $-9.539(p=0,555)$ & {$[-41.186 ; 22.107]$} \\
\hline $50-59$ & $7.564(p=0,658)$ & [-25.959; 41.087] & $29.282(p=0,053)$ & {$[-368 ; 58.933]$} \\
\hline $60-69$ & $-1.454(p=0,932)$ & {$[-34.701 ; 31.792]$} & $28.336(0=0,059)$ & {$[-1.131 ; 57.804]$} \\
\hline $70-79$ & $22.566(p=0,188)$ & {$[-11.005 ; 56.139]$} & $48.410(p=0,001)$ & {$[18.641 ; 78.179]$} \\
\hline$\geq 80$ & $13.593(p=0,440)$ & {$[-48.061 ; 20.873]$} & $43.478(p=0,007)$ & {$[12.095 ; 74.861]$} \\
\hline \multicolumn{5}{|c|}{ Nớ cư trú } \\
\hline Long Khánh & - & - & - & \\
\hline Xuần Lộc & $-24.057(p<0,001)$ & {$[-32.628 ; 15.486]$} & $-25.359(p<0,001)$ & {$[-33.742 ;-16.977]$} \\
\hline Cấm Mỹ & $-7.176(p=0,196)$ & {$[-18.054 ; 3.701]$} & $-8.541(p=0,110)$ & {$[-19.010 ; 1.927]$} \\
\hline Các vùng khác & $-23.628(p=0,006)$ & {$[-40.568 ;-6.689]$} & $-23.231(p=0,005)$ & {$[-39.475 ;-6.987]$} \\
\hline \multicolumn{5}{|c|}{ Bệnh măc kèm } \\
\hline Có & $-128.870(p<0,001)$ & {$[-138.912 ; 118.827]$} & $-122.568(p<0,001)$ & $-132.575 ;-112.561$ \\
\hline Không & - & & & \\
\hline \multicolumn{5}{|c|}{ Tình trạng BHYT } \\
\hline $100 \%$ & $74.200(p=0,118)$ & {$[-18.860 ; 167.262]$} & $81.777(p=0,099)$ & {$[-15.502 ; 179.057]$} \\
\hline $95 \%$ & $143.037(p=0,003)$ & {$[49.666 ; 236.409]$} & $140.842(p=0,005)$ & {$[43.346 ; 238.337]$} \\
\hline $80 \%$ & $112.313(p=0,018)$ & [19.389; 205.237] & $115.498(p=0,020)$ & {$[18.380 ; 212.616]$} \\
\hline Không có BHYT & - & - & - & - \\
\hline Dịch vụ y tế & & & & \\
\hline \multicolumn{5}{|c|}{ Thuốc } \\
\hline Có & $610.204(p<0,001)$ & [599.727; 620.682] & $611.761(p<0,001)$ & {$[602.185 ; 621.338]$} \\
\hline Không & - & - & - & - \\
\hline \multicolumn{5}{|c|}{ Xét nghiệm } \\
\hline Có & $152.963(p<0,001)$ & {$[147.252 ; 158.674]$} & $147.720(p<0,001)$ & {$[142.225 ; 153.214]$} \\
\hline Không & - & & - & - \\
\hline \multicolumn{5}{|c|}{ Chấn đoán hình ảnh } \\
\hline Có & $209.870(p<0,001)$ & [175.763; 243.977] & $166.648(p<0,001)$ & [133.479; 199.817] \\
\hline Không & - & - & - & - \\
\hline \multicolumn{5}{|c|}{ Dịch vụ khác } \\
\hline Có & $122.850(p<0,001)$ & [88.359; 157.340] & $53.532(p<0,001)$ & {$[23.439 ; 83.625]$} \\
\hline Không & - & - & - & \\
\hline
\end{tabular}


Ghi chú: Tất cả chi phí trong bảng đã được quy đổi về giá trị năm 2020. aMô hình tuyến tính tổng quát GLM đơn biến, kết quả trình bày trong bảng là giá trị phân tích biên sau mô hình, bMô hình tuyến tính tổng quát GLM đa biến, kết quả trình bày trong bảng là giá trị phân tích biên sau mô hình, 'KTC: khoảng tin cậy, 'Biến số bệnh kèm được sử dunng thay cho các biến số bểnh kèm cụ thể do hiện tượng cộng tuyến.

\section{BÀN LUẬN}

Trong giai đoan nghiên cứu cho thấy số lượng người bệnh ĐTÐ type 2 có tăng và chêch lệch rõ qua các năm 2016-2020, có tổng chi phí điều trị ngoại trú do BHYT chi trả chiếm $64,6 \%$ và phần còn lai do người bênh cùng chi trả chiếm 35,4\% với chi phí điều trị trung bình cho 1 ca bênh là 626.131 VND, gần tương đương với kết quả nghiên cứu của tác giả Nguyễn Thị Kim Loan có chi phí trung bình điều trị ca bệnh ĐTĐ type 2 là 652.111 VND [8]. Chi phí thuốc vẫn luôn là chi phí cao nhất chiếm $84 \%$ trong tổng chi trả trong các loại dịch vụ y tế. Do đó, BHYT thanh toán chi phí điều trị hàng quý đều tập trung vào chi phí sử dụng thuốc hợp lý trong điều trị ngoại trú bệnh ĐTĐ type 2 tại bệnh viện.

Sỗ lượng người bệnh ĐTÐ type 2 có xu hướng tăng trong những năm gần đây và tham gia BHYT tự nguyên nhiều, tuy nhiên BHYT có hợp đồng khám chữa bệnh với Bệnh viện và thanh toán tiên theo định xuất vào cuối kỳ nên cần có giám sát chặt chẽ chỉ định sử dụng thuốc hợp lý và thực hiện các dịch vụ y tế phù hợp với tình trạng bệnh ĐTĐ type 2 để tránh bị xuất toán từ quỹ BHYT. Như vậy, việc xây dựng một phác đồ điều trị bệnh ĐTĐ type 2 thích hợp, hiệu quả và tiết kiệm là một vấn đề phức tạp, cần có sự hướng dẫn cụ thể thống nhất từ các cơ quan quản lý, chuyên môn và BHYT. Nghiên cứu cơ sở dữ liệu BHYT quốc gia cho biết tổng chi phí trực tiếp BHYT chi trả cho người bênh ĐTÐ type 2 năm 2017 là 10,111 tỷ VND. Trong đó, khoảng $70 \%$ là các khoản chi trả liên quan đến biến chứng đi kèm, thuốc chỉ chiếm $14 \%$ tổng chi phí.

Kết quả nghiên cứu phân tích các yếu tố liên quan đến chi phí điêu trị bệnh ĐTĐ type 2 tại bệnh viện thông qua mô hình đơn biến và mô hình đa biến. Chi phí điều trị trung bình một hoặc nhiều nhóm phân tích sẽ được so sánh với một nhóm được lựa chọn là nhóm so sánh hay còn được gọi là nhóm có các đặc tính nền (không được thể hiện giá trị trong bảng).

Kết quả phân tích mô hình đơn biến cho thấy biến số về giới tính, bệnh mắc kèm, nơi cư trú và tham gia các dịch vụ y tế là các biến ảnh hưởng có ý nghĩa thống kê đối với chi phí điều trị bệnh ĐTĐ type 2. Cụ thể, đối với biến giới tính người bệnh có giới tính nam có chi phí trung bình thấp hởn 22.541 VND so với người bệnh có giới tính nữ. Nhóm người bệnh ở khu vực huyện Xuân lộc có chi phí trung bình thấp hởn khu vực thành phố Long Khánh là 24.057 VND. Đối với biến bệnh mắc kèm, người bệnh có bệnh mắc kèm có chi phí trung bình thấp hơn 128.870 VND so với nhóm không có bệnh mắc kèm. Về các nhóm người bệnh tham gia dịch vụ y tế: Nhóm người bệnh có sử dụng thuốc có chi phí trung bình cao hơn 610.204 VND so với nhóm không sử dụng thuốc; Nhóm người bệnh có xét nghiêm có chi phí trung bình cao hơn 152.963 VND so với nhóm không xét nghiệm; Nhóm người bệnh có chẩn đoán hình ảnh có chi phí trung bình cao hơn 209.870 VND so với nhóm không chẩn đoán hình ảnh và Nhóm người bệnh tham gia dịch vụ khác có chi phí trung bình cao hơn 122.850 VND so với nhóm không tham gia.

Kết quả phân tích hồi quy đa biến là hê số tác động của từng thông số và ảnh hưởng làm gia tăng chi phí của mỗi biến hồi quy so với đặc tính nền của phân tích. Từ kết quả phân tích, nghiên cứu đã ghi nhận được các biến ảnh hưởng có ý nghĩa thống kể đến chi phí điều trị ĐTĐ type 2 của người bệnh tại bệnh viện là nhóm tuổi từ 70 79 tuổi, nơi cư trú ở huyện Xuân Lộc, có mắc bệnh kèm và có tham gia các dịch vụ y tế (thuốc, xét nghiệm, chẩn đoán hình ảnh, dịch vụ khác).

\section{KẾT LUẦN}

Kết quả nghiên cứu chi phí trực tiếp cho y tế trong điêu trị ngoai trú bệnh ĐTĐ̇ type 2 đã ghi nhận được: tổng chi phí điều trị là 31.581.327.511 VND, trong đó BHYT chi trả $64,6 \%$ và người bệnh cùng chi trả $35,4 \%$. Chi phí trung bình cho điều trị một ca giảm dân theo thời gian từ 766.778 VND năm 2016 xuống 562.959 VND năm 2020. Các yếu tố liên quan đến chi phí trực tiếp cho y tế bao gồm giới tính, nơi cư trú, bệnh kèm, mức bảo hiểm y tế, sứ dụng các dịch vụ y tế.

\section{TÀI LIÊU THAM KHẢO}

1. Trường Đại học Y Hà Nội (2019), Dịch tễ học một số bệnh phổ biến, Nhà xuất bản y học, Hà Nổi, tr.267-271.

2. Bố Y tế (2020), Hướng dẫn chẩn đoán và điều trị đải tháo đường type 2, Quyêtt định số 5481/QĐBYT, 3्र11/12/2020, Hà Nội, tr.18-20,58-73.

3. Nguyển Ngọc Khôi, Đặng Nguyê̂n Đoan Trang (2021), Khoa Dược-Bộ mồn Dước lâm sàng, Dược lâm sàng và điều trị, Nhà xuất bản y học, Chi 
nhánh thành phố Hồ Chí Minh, tr.418- 454

4. International Diabetes Federation (2019), "Diabetes Atlas Ninth edition 2019".

5. Bộ Y tế (2019), Hướng dẫn thực hành dược lâm sảng cho dược sĩ trong một sổ bệnh không lây nhiểm, Quyết định số 3809/QĐ-BYT, 27/08/2019, Nhà xuất bản y học, Hà Nội, tr.15-43.

6. Đào Văn Dũng (2020), P̉hương pháp nghiên cứu khoa học-Nghiên cứu hệ thống y tế, Nhà xuất bản y học, Hà Nội, tr.210-235.
7. Phạm Đình Luyến, Nguyễn Thị Hải Yến (2020), Khoa Dược-Bộ môn Quản lý dược, Kinh tế dươc, Tập 1 , Nhà xuất bản y học, Chi nhánh thành phố Hồ Chí Minh, tr.207-210.

8. Nguyê̂n Thi Kim Loan (2018) Phân tích chi phí điêu trị đái tháo đường type 2 tai bênh viên Đa khoa vạn Hạnh giai đoan 2013-2017, Luận văn Dược sĩ chuyên khoa cấp II, Trường Đại học Y Dược thành phố Hồ Chí Minh, tr.43-47, 48-70.

\section{KẾT QUẢ PHẪU THUÂT NộI SOI ĐÎ̂̀U TRI ĐỨT DÂY CHẰNG CHÉO TRƯớC Có SỬ DỤNG VẬT LIỆU HỖ TRỢ BÊN TRONG}

\section{TÓM TẮT}

Muc tiêu của nghiên cứu nhằm đánh giá kết quả phẫu thuật nội soi điều trị đứt dây chằng chéo trước có sử dụng vật liệu hỗ trợbên trong. Thiết kế nghiên cứu can thiệp lâm sàng không đối chứng trên 31 bệnh nhân được chẩn đoán đứt dây chằng chéo trước và được phẫu thuật nội soi điều trị bằng nepp hỗ trợ bên trong (internal brace)tại Bệnh viện Đại học Y Hà Nội và Bệnh viện Đa khoa Saint Paull, từ tháng 01/2019 đến tháng 12/2020. Kết quả cho thây tuổi trung bình là 29,87 $\pm 7,9$; tỷ số nam/nữ $=4,2$; Thời gian phẫu thuật trung bình là là $102,3 \pm 15,5$ phút, thời gian nằm viện trung bình là $6,0 \pm 1,0$ ngày.Thang điểm Lysholm trước phẫu thuật trung bình là 60,2 $\pm 3,7$.Sau phẫu thuất 6 tháng, giá trị trung bình của điểm Lysholm được cải thiện tốt $(91,2 \pm 11,7)$;tỷ lệ đạt kết quả tốt và rất tốt $(87,1 \%)$. Điểm mức độ hoạt động Tegner trung bình trước chấn thương là6,3 30,6 (dao động từ 5-7); trước phẫu thuât là $3,3 \pm 1,1$ (dao động từ 1-5). Tại thời điểm sáu tháng sau phẫu thuật, giá trị trung bình của điểm này là $5,0 \pm 1,2$ (dao động từ 27). Phẫu thuật nội soi điều trị đứt dây chằng chéo trước có sử dụng vật liệu hỗ trợ bên trong cho kết quả rất khả quan. brace

Tư khóa: dây chằng chéo trước, nội soi, internal

\section{SUMMARY \\ OUTCOME OF ARTHROSCOPIC TREATMENT ANTERIOR CRUCIATE LIAGMENT TEAR BACK UP WITH INTERNAL BRACE}

Objective of the study was to evaluate the results ofarthroscopic treatment anterior cruciate ligament tear back up with internal brace. A clinical intervention study design was applied in 31 patients diagnosed with anterior cruciate ligament tear and treated by

\footnotetext{
${ }^{1}$ Trường Đai hoc Y Hà Nôi,

${ }^{2}$ Bệnh viện Đại học Y Hà Nội

Chiu trách nhiệm chính: Đào Xuân Thành

Email: daoxuanthanh@hmu.edu.vn

Ngày nhận bài: 16.8.2021

Ngày phản biện khoa học: 15.10.2021

Ngày duyệt bài: 22.10.2021
}

Vũ Trung Hiếu ${ }^{1}$, Đào Xuân Thành ${ }^{1,2}$

arthroscopic back up with internal brace in Hanoi Medical University Hospital and Saint Paul Hospital from January 2019 to December 2020 wererecruited. Results shown that mean age was $29.87 \pm 7.9$ years, male/female ratio was 4.2. The mean time of operation was $102.3 \pm 15.5$ minutesand the average length of hospitalizationwas $6.0 \pm 1.0$ days. The average preoperative Lysholm score was $60.2 \pm 3.7$. At six months after operation, the average score improved to $91.2 \pm 11.7$. The excellent and good result was $87,1 \%$. The average Tegner Activity score before injury was $6.3 \pm 0.6$ (range from 5 to 7 ); average preoperative score was $3.3 \pm 1.1$ (range from 1 to 5 ). At six months after operation, the average value of this score was $5.0 \pm 1.2$ (range from 2 to 7 ).

Keywords: anterior crucuiate ligament, arthroscopic surgery, internal brace

\section{I. ĐĂT VẤN ĐỀ}

Đứt dây chằng chéo trước là chấn thương thường gặp vùng gối. Hiện nay điều trị đứt dây chằng chéo trước bao gồm bảo tồn và phẫu thuật. Phẫu thuật có 2 phương pháp chínhlà nội soi tái tạovà nồi soi sửa chữa. Sửa chữa dây chằng chéo trước trong trường hợp bệnh nhân đến sớm, đứt tại điểm bám lồi cầu đùi và chất lượng dây chằng còn tốt. ${ }^{1}$ Phương pháp phẫu thuật thứ hai là tái tạo dây chằng chéo trước bằng gân tự thân, đồng loại hoặc nhân tạo. Đây được xem là tiêu chuấn vàng trong điều trị đứt dây chằng hiện nay.Dù là sửa chữa hay tái tạo thì sức mạnh dây chằng mới sẽ khôngđược như ban đầu và có nguy cơ đứt lại.

Để hạn chế biến chứng trên thì gần đây có một phương pháp gia cố tăng cường sức mạnh dây chằng đó là sử dụng vật liệu hỗ trợ bên trong (Internal Brace-IB). Vật liệu này là một sợi cáp được bện bằng nhiều sợi tổng hợp có tên là FiberTap - đã chứng minh được khả năng chiu lực rất tốt. FiberTap đóng vai trò như một "dầy đai an toàn", giới hạn mức độ giãn của mảnh ghép DCCT, giảm thiểu tối đa nguy cơ đứt lại 